ORIGINAL ARTICLE

\title{
Quality planning of silvicultural operations in eucalyptus in Brazil
}

\author{
Planejamento da qualidade de operações silviculturais em eucalipto no \\ Brasil
}

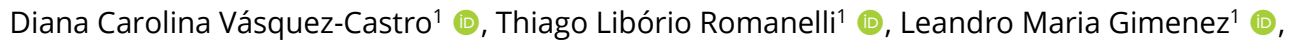 \\ Marcos Milan ${ }^{1}$ (1) \\ ${ }^{1}$ Universidade de São Paulo - USP, Piracicaba, Brasil
}

\author{
How to cite: Vásquez-Castro, D. C., Romanelli, T. L., Gimenez, L. M., \& Milan, M. (2021). Quality planning of \\ silvicultural operations in eucalyptus in Brazil. Scientia Forestalis, 49(129), e3317. \\ https://doi.org/10.18671/scifor.v49n129.09
}

\begin{abstract}
To guarantee quality and competitiveness of products and processes, it is necessary to plan them from the initial stage and to integrate this planning into the production process. There are several processes involved in forest production, from planting to harvesting. These processes must be planned to ensure that the needs of the crop - one of the customers - are fulfilled. Therefore, this study aimed to plan the technical characteristics from silvicultural process to fulfill the needs of eucalyptus crop. Quality function deployment (QFD) was applied considering eucalyptus as a customer. The study was carried out on commercial plantations located in São Paulo State, Brazil. In total, 48 items related to the quality required by the customer - "What"- and 79 technical characteristics -"How"- were defined, resulting on 3,792 possible relationships used to translate "What" into "How". Out of this total, 874 presented relationships - "What" versus "How" - and based on the relationships, the technical characteristics were weighted according to their perceived importance. Forest productivity, seedling replacement and four other activities related to soil tillage were considered as the most important ones. Evaluations of "How" vs. "How" - resulted in 6,241 possible correlations, 252 out of which were positive or negative. These correlations can bring benefits when positive, but can also negatively influence the development of plantations. For implantation, soil clay content presented several correlations with other characteristics that could bring benefits, but also negative effects, such as less root penetration, depending on the soil moisture. To ensure that the needs of the eucalyptus and consequently of the industry are met, seedling replacement and four other technical characteristics related to soil preparation were considered as the most important for the silvicultural process.
\end{abstract}

Keywords: Implanted forests; Product planning; Processes; QFD.

\section{Resumo}

Para garantir a qualidade e competitividade dos produtos e processos, é necessário planejar desde o estágio inicial e integrar esse planejamento ao processo produtivo. Para a implantação das florestas existem vários processos envolvidos desde o plantio até a colheita e estes processos devem ser planejados para garantir que as necessidades da cultura, cliente, sejam atendidas e com isso o objetivo deste trabalho foi planejar as características técnicas envolvidas no processo silvicultural para atender as necessidades da cultura de eucalipto. A metodologia aplicada foi a função desdobramento da qualidade (QFD) considerando o eucalipto como cliente. O estudo foi realizado em uma plantação comercial localizada no estado de São Paulo, Brasil. No total, 48 itens relacionados à qualidade exigida pelo cliente e 79 características técnicas foram definidos, totalizando 3792 relações possíveis. Deste total, 874 tiveram relações - "o Que" versus "Como" -, e com base nas relações as características técnicas foram

Financial support: PEC-PG CNPq Conselho Nacional de Desenvolvimento Científico e Tecnológico - CNPq (Scholarship 15062120).

Conflict of interest: Nothing to declare.

Corresponding author: dianavasquez@alumni.usp.br

Received: 19 March 2019.

Accepted: 16 December 2019.

Editor: Paulo Henrique Müller Silva. (c) This is an Open Access article distributed under the terms of the Creative Commons Attribution License, which permits unrestricted use,
distribution, and reproduction in any medium, provided the original work is properly cited. 
classificadas por peso relativo. A produtividade florestal, o replantio e outras quatro atividades relacionadas ao preparo do solo foram os mais importantes. Avaliações de - "Como" versus "Como" resultaram em 6241 possíveis correlações, das quais 252 apresentaram correlações, positivas ou negativas. Essas correlações podem trazer benefícios quando positivas, mas também podem influenciar negativamente o desenvolvimento das plantações. Na implantação o teor de argila do solo apresentou diversas correlações com outras características que podem trazer benefícios, mas também efeitos negativos, como a dificuldade de penetração das raízes, dependendo da umidade do solo. Para atender as necessidades da cultura do eucalipto e consequentemente da indústria, replantio e quatro outras características técnicas relativas ao preparo do solo foram consideradas como as mais importantes para o processo silvicultural.

Palavras-chave: Florestas implantadas; Planejamento de produto; Processos; QFD.

\section{INTRODUCTION}

Many companies are still characterized by developing their products with an internal vision to it, a fact that goes back to the times of scientific administration (Govers, 1996). This type of development may not fulfill the needs of customers, diminishing competitiveness and jeopardizing the company survival. To maintain competitiveness, it is necessary to develop products and processes from customers' expectations, otherwise the risk of failure in the market or of extending development time is high (Zairi \& Youssef, 1995).

Quality planning allows for the development of products and processes that fulfill the customers' needs. For this to happen, it is necessary to capture and transmit these needs to the project, ensuring that the requirements are incorporated (Akao,1997). Planning phase is the period in which the characteristics of the process can be widely known, and the faults identified (Juran, 1992). After transmitting the captured needs, it is necessary to integrate the project within the production processes to guarantee product quality from start to finish, which results into gains for the company (Andrade \& Fernandes, 2018).

In forestry, silvicultural processes used to produce eucalyptus must fulfill the industrial demand, which requires timber quality, at the right time and in adequate quantities. To supply the industry, processes must be planned from the initial stages to fulfill the needs of the plants that will establish the forest to be harvested. As a living being, eucalyptus has its needs and expectations and attending them is a way to guarantee the quality and productivity demanded by the industry. The eucalyptus should be considered as a customer in the processes.

There are several processes within implantation and conduction of a planted forest that involve: soil tillage, planting, pest, disease and weed controls, and others. These processes are usually analyzed by studies such as presented by Gonçalves et al. (2016) evaluating the depth, shape and distance between grooves in the subsoiling operation for the implantation of forests. They showed that process quality can contribute to increasing productivity and reducing costs. Baptista \& Levien (2010) comment on the importance of soil tillage for root growth and for water and nutrients absorptions, but, controversially, that tillage can accelerate water erosion. These authors quantified the effect of different subsoiling on soil tillage regarding water erosion and biomass accumulation and one of the requirements evaluated was the volume of soil mobilized in the process. Medauar et al. (2018) used the spectrum of drops and the rate of application as requirements to assess the quality of herbicide spraying in forest areas. Spraying is a process that aims to reduce the potential competition for light, water and nutrients between weeds and planted trees.

Therefore, quality requirements were evaluated individually in the processes, but to guarantee the quality and competitiveness of the companies it is necessary to plan the product from the design phase and integrate this planning into the process. Therefore, this study aimed to plan the technical characteristics involved in the silvicultural process to fulfil the needs of the eucalyptus plantation. 


\section{MATERIALS AND METHODS}

To fulfill the objective of this study, the methodology of Quality Function Deployment (QFD) was applied according to Cheng et al. (1995) and Govers (1996). Also known as House of Quality, this method regards the definition of which product is to be developed, the customers' requirement (Whats), the importance degree of each requirement on the customers' point of view, the evaluation of competitiveness, the translation of customers' requirements into technical requirements (Hows) and the correlations Whats versus Hows and Hows versus Hows (Figure 1).

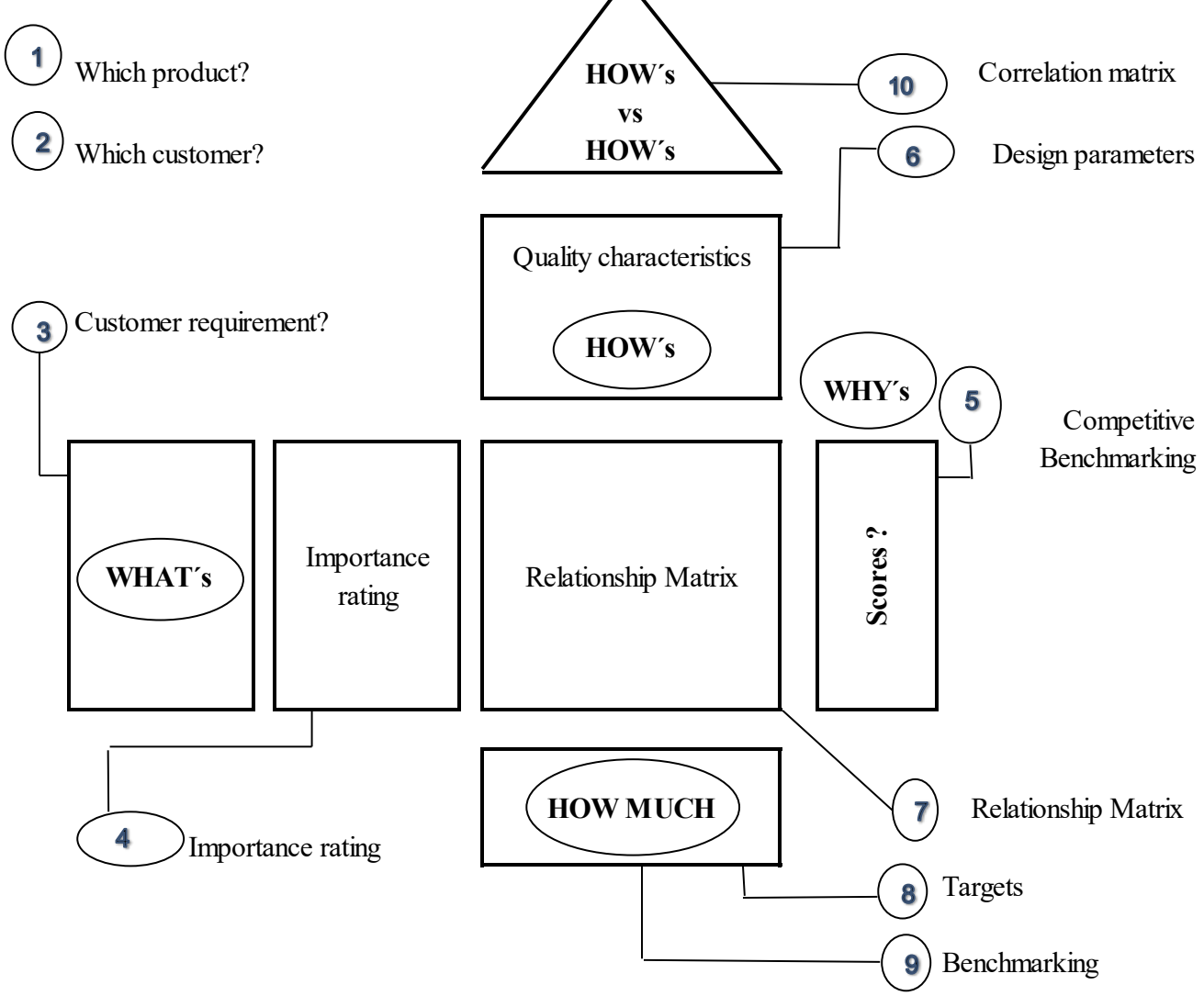

Figure 1- Phases of the House of Quality - Adapted from Cheng et al. (1995) and Govers (1996).

Figure 1 presents the 10 phases employed in this study development. From a Brazilian forestry company, a team of six experts was put together to develop these phases. Additionally, there was a moderator to guide activities regarding the House of Quality. In phase 1, (Which product?), the requirements of operational processes of eucalyptus production were considered as the product, whose customer, phase 2, (Which customer?) was the eucalyptus plantation. A bibliographic survey about the requirements of silvicultural processes to fulfill the customer (eucalyptus) was carried out to define the demanded quality/customer claim "(Whats)", phase 3, (Customer requirement). Items were organized through a tree diagram, unfolding up to the third level and validated by the expert team. It also defined the importance degree, phase 4, (Importance rate) for each item of customer requirement using a scale from 1 to 5 , with a value of 1 being unimportant and 5 very important.

In Phase 5, benchmarking was carried out by specialists between a farm adopted as the standard scenario: Farm_01, located in São Paulo State and Farm_02, located in Maranhão State, both in Brazil. For every item of required quality, the expert team defined the plan and the improvement index for the production scenario. Values adopted for the technical argument were 1.0 - neutral, 1.2 - average, and 1.5 - important. These values allow 
highlighting the most important items for quality. Absolute and relative weights for each item regarding planned quality were determined according Equations 1 and 2.

$\mathrm{PAi}=\mathrm{GI} \times \mathrm{IMi} \times \mathrm{AVi}$

Where: $\mathrm{PA}_{\mathrm{i}}=$ absolute weight for the required quality of the $\mathrm{i}$-th item, $\mathrm{Gli}=$ importance degree of the i-th item, non-dimensional; $\mathrm{IM}_{\mathrm{i}}=$ Improvement index of the i-th item, non-dimensional; $\mathrm{AV}_{\mathrm{i}}=$ Technical argument of the i-th item, non-dimensional;

$\mathrm{PRi}=\left(\frac{\mathrm{PAi}}{\sum_{\mathrm{i}=1}^{\mathrm{n}} \mathrm{PAi}}\right) \times 100$

Where: $\mathrm{PRi}^{=}$Relative weight of the required quality of the i-th item (\%).

Process mapping was used to define the production phases and from these phases, the experts defined the technical characteristics, "Hows", phase 6, (Quality characteristics) to fulfill the quality required by customers (phase 3 , "Whats"). After that, the experts established the relation between "Hows" and "Whats", phase 7, through weights to classify the importance of these relations: strong (9); average (3); weak (1) and inexistent (0).

Values, absolute and relatives, used to prioritize technical characteristics, were determined according to Equations 3 and 4, phase 8, (Targets), and the experts technically compared the standard scenario, Farm_01and Farm_02, phase 9.

$P A_{j i}=\sum_{j=1}^{m} \sum_{i=1}^{n} C_{j i}$

Where: $\mathrm{PA}_{\mathrm{ji}}=$ Absolute weight of quality characteristics of the $\mathrm{j}$-th item, non-dimensional; $\mathrm{C}_{\mathrm{ji}}=$ weight of the relation of the $\mathrm{j}$-th quality characteristics and i.th required quality, nondimensional; $i=$ required quality; $j=$ quality characteristics; $m=$ items of quality characteristics; $n=$ items of required quality;

$P R j i=\left(\frac{P A j i}{\sum_{i=1}^{n} P A j i}\right) \times 100$

Where: PRji = Relative weight of items of required quality of $\mathrm{i}$-th item. Goals to assure that the requisites of quality were also established.

The experts performed the correlation among the items of "Hows", phase 10, (correlation matrix), ranking correlations according to trends. If an item affects another positively in a way both are benefited, the correlation is strongly positive or positive; if the effect is not beneficial, so it is ranked as negative or strongly negative; items without correlation are not ranked.

\section{RESULTS AND DISCUSSION}

Based on the definition of the product evaluated (phase 1) performed by the expert team on the process requirements and on the customer - eucalyptus (phase 2), the team defined the customer's requirements (Whats) in terms of quality of the silvicultural processes (phase 3 ) for forestry production. In total, 48 items were indicated and ranked in 7 processes: management, planning, soil tillage, planting, fertilization, weed, plagues and diseases. The team attributed the degree of importance for 48 items (phase 4). Extraction of quality characteristics (Hows) based on process mapping (phase 6) and from the items of required quality resulted in 79 technical characteristics, ranked in 8 groups: seedling quality, soil tillage, planting, management practices, environment, supplies, work shift, machinery. Identification of influence degree between 
required quality and quality characteristics - correlation (phase 7) resulted in 3792 possible relations between "Whats" and "Hows". Out of those, 874 presented relationship being 375 considered as strong, 322 as average, 177 as weak and 2918 without influence. Evaluations of the interdependency and sense of quality characteristics - "How" versus "How" (phase 10) resulted in 6241 possible interdependencies. Out of those, 252 presented correlations being 49 strongly positive, 121 positive, 62 negative, 14 strongly negative and 5989 without correlation and interdependency. A partial view of the matrix is presented in Figure 2.

CUSTOMER REQUIREMENT

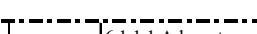

\begin{tabular}{|c|c|c|c|c|}
\hline \multirow{6}{*}{$\begin{array}{l}\text { 6. Plants } \\
\text { weeds }\end{array}$} & \multirow{6}{*}{$\begin{array}{c}6.1 \text { Ensure full } \\
\text { development of } \\
\text { the seedlings } \\
\text { avoiding } \\
\text { competition } \\
\text { with weeds }\end{array}$} & \multirow{6}{*}{$\begin{array}{l}6.1 .1 \text { Weed } \\
\text { control }\end{array}$} & $\begin{array}{l}\text { 6.1.1.1 Adequate weeds } \\
\text { chemical (...) }\end{array}$ & 1 \\
\hline & & & 6.1.1.2 Product quality & 2 \\
\hline & & & $\begin{array}{l}\text { 6.1.1.3 Application in the right } \\
\text { place }\end{array}$ & 3 \\
\hline & & & $\begin{array}{l}\text { 6.1.1.4 Herbicide application } \\
(\ldots)\end{array}$ & 1 \\
\hline & & & $\begin{array}{l}\text { 6.1.1.5 Heigher product action } \\
\text { time }\end{array}$ & 2 \\
\hline & & & $\begin{array}{l}\text { 6.1.1.6 Prevention, control and } \\
\text { monitoring }\end{array}$ & 1 \\
\hline
\end{tabular}
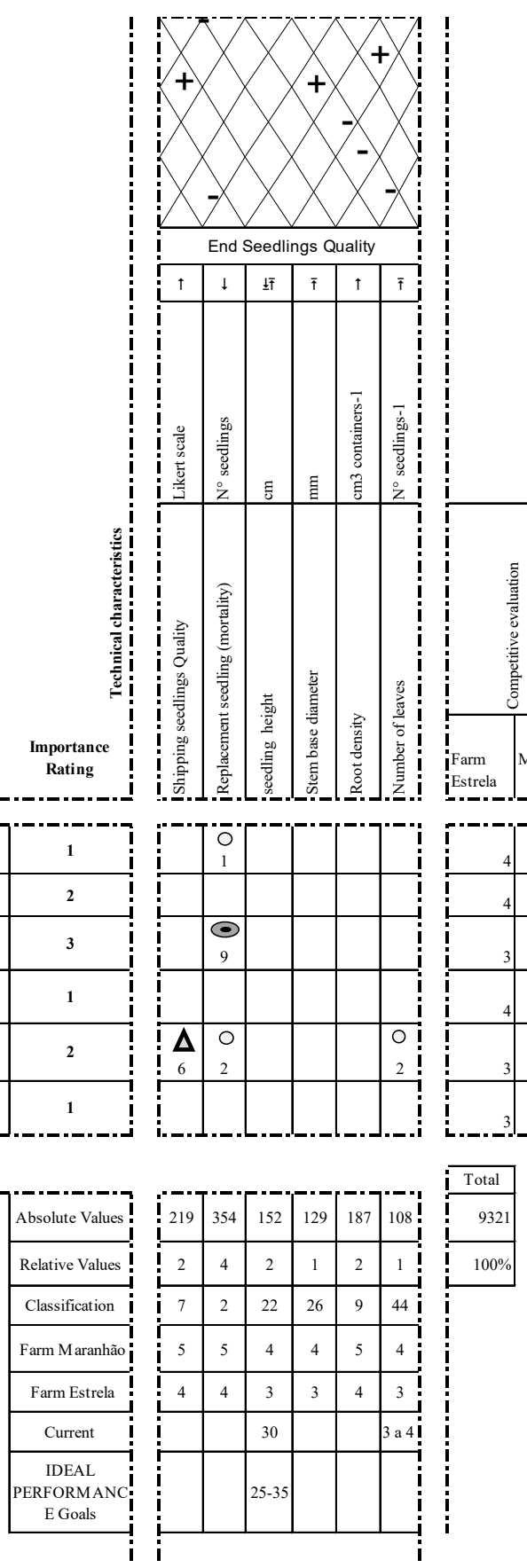
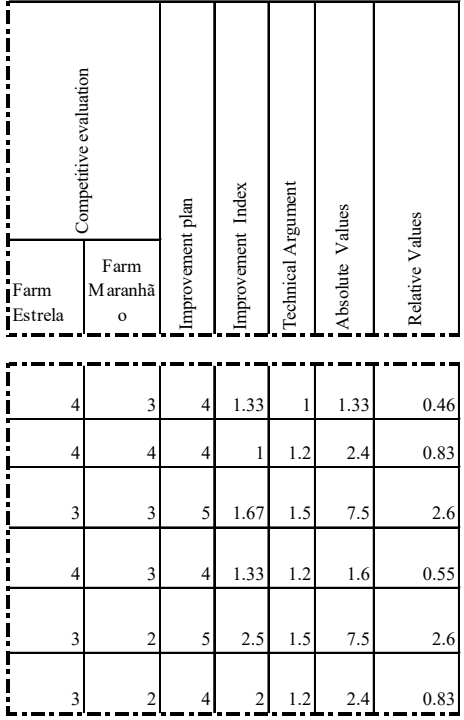

$[288.8 \div \overline{100 \%}]$

Figure 2- Partial view of the matrix

The team attributed the degree of importance for 48 items, phase 4, resulting in nine items ranked as unimportant, ten as lightly important, nine as moderately important, ten as important and ten as very important. Out of the 48 items referred to expected quality, planting 
is emphasized; Table 1. Planting presented eight items ( $17 \%$ of total), of which four received degree 5 , showing the importance of the process on the customer's point of view.

Table 1 - Distribution of importance rating value assigned to the qualities required of the processes.

\begin{tabular}{|c|c|c|c|c|c|c|c|}
\hline \multirow{3}{*}{ Process } & \multicolumn{7}{|c|}{ Importance Rating Value } \\
\hline & \multicolumn{5}{|c|}{ Quantity } & \multirow{2}{*}{ Total } & \multirow{2}{*}{ Perc. \% } \\
\hline & 1 & 2 & 3 & 4 & 5 & & \\
\hline Management & 0 & 4 & 1 & 4 & 2 & 11 & 22.9 \\
\hline Planning & 0 & 1 & 2 & 0 & 2 & 5 & 10.4 \\
\hline Soil preparation & 1 & 0 & 3 & 2 & 1 & 7 & 14.6 \\
\hline Planting & 0 & 2 & 0 & 2 & 4 & 8 & 16.7 \\
\hline Fertilization & 2 & 1 & 2 & 1 & 1 & 7 & 14.6 \\
\hline Plants weeds & 3 & 2 & 1 & 0 & 0 & 6 & 12.5 \\
\hline Pest and diseases & 3 & 0 & 0 & 1 & 0 & 4 & 8.3 \\
\hline Total & 9 & 10 & 9 & 10 & 10 & 48 & 100.0 \\
\hline
\end{tabular}

For plant and diseases, four quality items were defined (8.3\%), three of them received degree 1 showing little importance for the customer. Justification was that once the deadline for plague and disease control defined, the control performance would be adequate. Management had the largest number of items, 11 (22.9\%), being two ranked as degree 5 and four as degree 4 . The amount of process items and their ranking show how important it is for the customer, because management performs the monitoring of other processes aiming the sustainability of the production system.

Planned quality, phase 5, highlights the prioritized items for the product development. Priority is given by the index of relative weight, which considers the degree of importance (customer's preference), improvement to be achieved, preference that customer has about the product, and the technical argument, strategical benefits that each item has for the product, Figure 3.

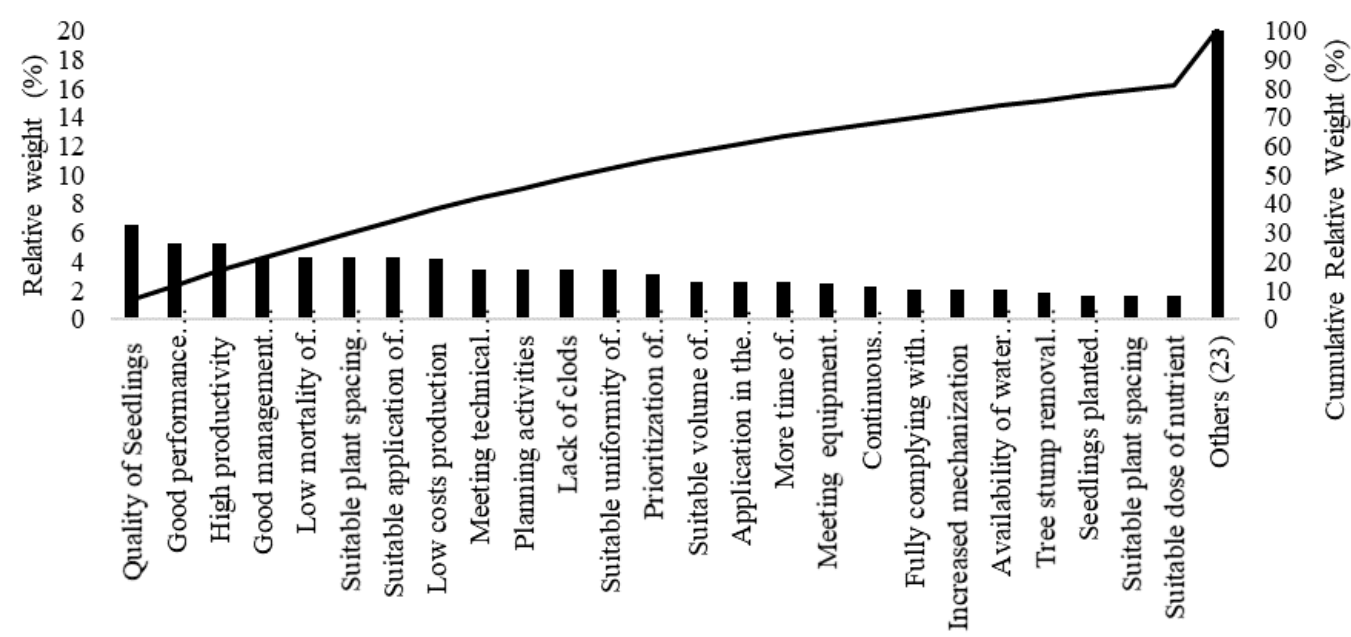

Figure 3- Priority items of Planned quality

The prioritized item for the product development is the seedling quality, (regarding planting), followed by a good performance of indicators (management) and high yield (management). Kim et al. (2015) showed that seedlings should present the desired characteristics on phytosanitary, morphological, physiological, vigor quality, among others, which are necessary for the development and yield of a eucalyptus forests. Regarding the 
good performance of indicators, Soares et al. (2015) defined the main indicators for weed control in forest plantations. With them, weed can be monitored without damaging the forest development, a customer's requisite. Cordeiro et al. (2009) defined the indicators regarding the benefits and aspects to be improved in the forestry development with eucalyptus, due to the importance of promotion to generate income and jobs in rural properties.

The importance of each item of required quality; with importance a degree defined by customer, can be changed for the improvements to be achieved due to the comparison between Farm_01 and Farm_02 and the benefits to be embodied to the product; Figure 4. With this change, items of required quality that receive importance degree 4 would have more relative weight that those receiving 5 . In this case, only two items with importance degree 4 presented relative weight of planned quality below items with importance degree 5.

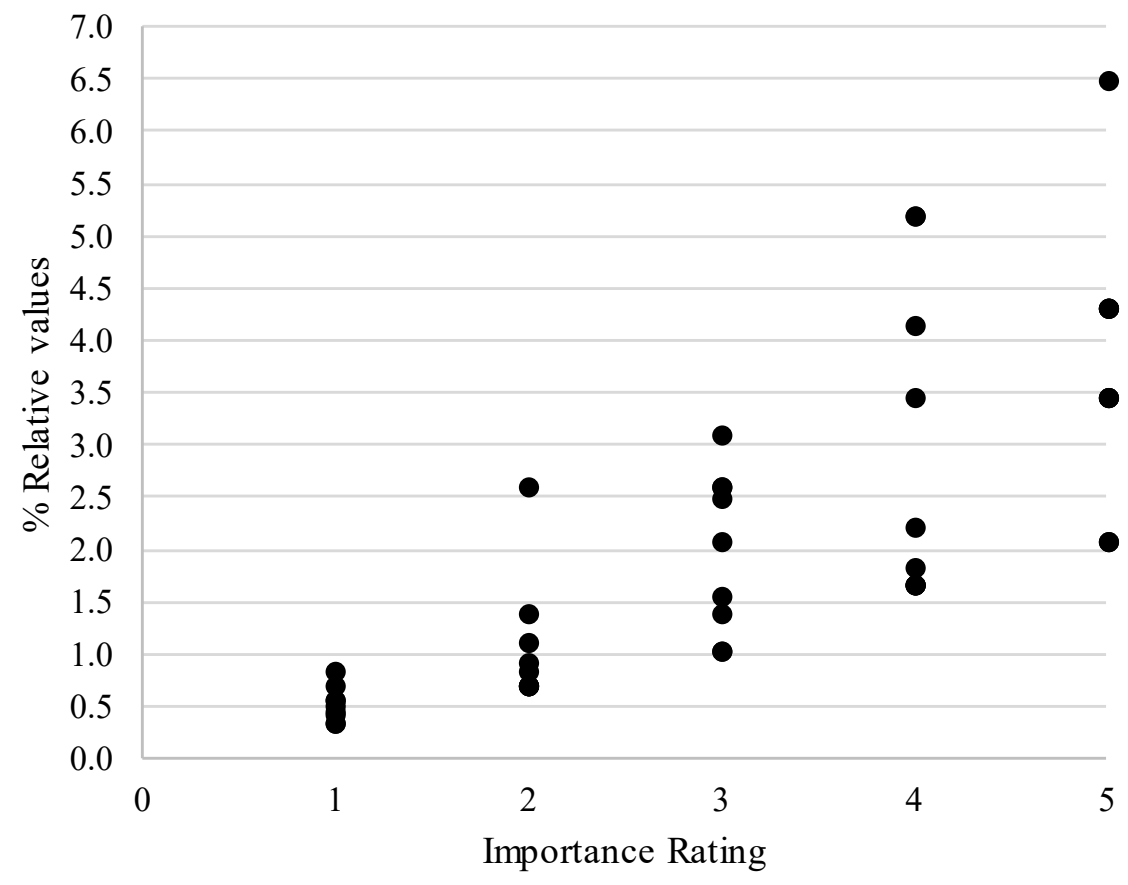

Figure 4 - Relationship between the relative values and importance rating

Transformation of customer claim - items of required quality ("Whats") - into technical, quality characteristics ("Hows"), correlation between them ("Whats" versus "Hows") and conversion of weight of required quality to quality characteristics (phases 6 to 8) allow prioritizing the technical characteristics - relative importance. Technical characteristics ranked as the most important in the silvicultural process were: forest productivity $7.6 \%$, seedling replacement $3.8 \%$, ripping depth $3.2 \%$, suitable soil volume $3.2 \%$, ripping width $3.2 \%$. Forest productivity had the higher relative weight in conversion evidencing the importance of using intensive silvicultural methods that result in higher yield and less mortality (Gonçalves et al. 2004; Schönau, 1984). As a technical characteristic, seedling replacement got the second position and it is associated to keep plant population per area, which corroborates yield increase. For Farm_01, this characteristic was ranked lower than for Farm_02 in the comparative evaluation (phase 9), indicating possibility of improvement. Characteristics number 3, 4, 5 and 6 (Table 2) presented the same classification ( $3^{\text {rd }}$ place), meaning that soil tillage is extremely important for the customer (eucalyptus plantation) and that Farm_01 has more possibility to improve than Farm_02. Furrow depth was one of the 
main characteristics of soil tillage, according to Milan et al. (2003) to fulfill the demand of eucalyptus seedlings.

Table 2 - Comparative evaluation of technical characteristics

\begin{tabular}{|c|c|c|c|c|c|c|}
\hline \multirow{3}{*}{$\begin{array}{l}\text { ऐ̀ } \\
\text { है } \\
\text { 三̇ } \\
\mathbf{z}\end{array}$} & \multirow{3}{*}{ Technical Characteristics } & \multicolumn{3}{|c|}{ Projected Quality } & \multirow{2}{*}{\multicolumn{2}{|c|}{$\begin{array}{l}\text { Farm Evaluation } \\
\text { Comparative }\end{array}$}} \\
\hline & & \multicolumn{2}{|c|}{ Values } & \multirow{2}{*}{ Rank } & & \\
\hline & & Absolute & Relative \% & & Farm_01 & Farm_02 \\
\hline 1 & Forest Productivity & 711 & 7.63 & 1 & 5 & 5 \\
\hline 2 & Replacement seedling (mortality) & 354 & 3.80 & 2 & 4 & 5 \\
\hline 3 & Ripping depth & 306 & 3.28 & 3 & 4 & 5 \\
\hline 4 & Suitable soil volume & 306 & 3.28 & 3 & 4 & 5 \\
\hline 5 & Ripping Width & 306 & 3.28 & 3 & 4 & 4 \\
\hline 6 & Soil penetration resistance & 306 & 3.28 & 3 & 4 & 5 \\
\hline 7 & Shipping seedlings Quality & 219 & 2.35 & 7 & 4 & 5 \\
\hline 8 & Weed Infestation & 197 & 2.11 & 8 & 4 & 5 \\
\hline 9 & Root density & 187 & 2.01 & 9 & 4 & 5 \\
\hline 10 & Fertilizer amount & 181 & 1.94 & 10 & 4 & 4 \\
\hline 11 & Pre emergent herbicide (SPCA) & 175 & 1.88 & 11 & 4 & 5 \\
\hline 12 & Post-emergent herbicide (SPCA) & 175 & 1.88 & 11 & 4 & 5 \\
\hline 13 & Pre-emergent herbicide (CT) & 175 & 1.88 & 11 & 4 & 5 \\
\hline 14 & Post-emergent herbicide (CT) & 175 & 1.88 & 11 & 4 & 5 \\
\hline 15 & Pest infestation & 170 & 1.82 & 15 & 4 & 4 \\
\hline 16 & Disease infestation & 170 & 1.82 & 15 & 4 & 4 \\
\hline 17 & Presence of anthills & 170 & 1.82 & 15 & 4 & 3 \\
\hline 18 & Number of accidents & 166 & 1.78 & 18 & 4 & 4 \\
\hline
\end{tabular}

SPCA- Soil preparation- cleaning area; CT- Cultural treatments.

Regarding the correlations among technical characteristics (phase 10 - "How's" versus "How's"), out of the 6241 possibilities, 252 presented correlation. Clay content and forest yield were the items that most presented interdependency with 23 each; Table 3. For clay content, two were classified as strongly negative and two as negative, indicating that clay content may compromise the performance of four out of 78 technical characteristics. On the other hand, 19 out of 23 were ranked with positive interference, indicating that clay content brings benefits for 19 characteristics out of 78, being 18 ranked positive and one strongly positive. Clay content has strongly positive correlation with soil organic matter; indicating the higher its content the higher is the organic matter concentration in the soil, which provides benefits for the eucalyptus development.

One of the characteristics that clay content affects positively is yield. On an experiment carried out by Cox et al. (2003), areas with higher clay content presented higher yields. In the characteristics related to soil, Elbanna and Witney (1987) stated that soil resistance to penetration changes according to moisture, and those high levels of resistance to penetration were found in clayey soil with moisture below $25 \%$, which harms root penetration. Moisture is vital to loosen soils with considerable clay content, but high clay contents holds more organic matter that is beneficial for plant development. Forest productivity had interdependency with 23 characteristics, being one strongly negative, three negative, six positive and 13 strongly positive. The characteristics weed infestation, clod diameter, soil resistance; presence of termites and ants were those that had negative correlation with forest productivity. In this case, it is necessary to pay attention to the levels reached by these characteristics, avoiding harms to the customer: eucalyptus. 
Table 3 - Technical characteristics with more relation of interdependency in the silvicultural processes of eucalyptus production.

\begin{tabular}{ccccccccc}
\hline \multirow{2}{*}{$\begin{array}{c}\text { Technical Characteristics } \\
\text { (How's) }\end{array}$} & \multicolumn{7}{c}{ Number of Correlation (interdependence) } \\
\cline { 2 - 8 } & Pos. & Spos. & TPos & Neg. & Sneg. & TNeg & Total \\
\hline Clay content & 18 & 1 & 19 & 2 & 2 & 4 & 23 \\
Forest Productivity & 13 & 6 & 19 & 3 & 1 & 4 & 23 \\
Replacement seedling & 9 & 3 & 12 & 1 & 6 & 7 & 19 \\
Shipping seedlings Quality & 9 & 7 & 16 & 0 & 0 & 0 & 16 \\
Soil moisture & 4 & 5 & 9 & 5 & 1 & 6 & 15 \\
\hline
\end{tabular}

Pos. Positive; SPos: Strongly Positive; TPos: Total Positive. Neg.: Negative; SNeg: Strongly Negative; Tneg: Total Negative

\section{CONCLUSIONS}

To ensure that the needs of the eucalyptus and consequently of the industry are met, seed replacement and four other technical characteristics related to soil tillage were considered as the most important for the silvicultural process. Nevertheless, in planning silvicultural activities, which is a process of high importance for the customer (eucalyptus), it is necessary to evaluate the values to be attributed to the characteristics, because correlations among the characteristics can negatively affect forest such as seedling replacement. Soil type has strong influence, since clay content presents several correlations with other characteristics that can bring benefits such as organic matter content but also negative effects such as root penetration under certain moisture limits.

\section{ACKNOWLEDGEMENTS}

Financial support of this study came from National Council of Scientific and Technical Knowledge (PEC-PG, CAPES - \#15062120).

\section{REFERENCES}

Akao, Y. (1997). QFD: past, present, and future. In Proceedings of International Symposium on QFD'97 (pp. 19-29). Linkoping: Linkoping University.

Andrade, J. H., \& Fernandes, F. C. F. (2018). Barreiras e desafios para a melhoria da integração interfuncional entre desenvolvimento de produto e planejamento e controle da produção em ambiente engineering-to-order. Gestão \& Produção, 25(3), 610-625. http://dx.doi.org/10.1590/0104$530 \times 1087-13$

Baptista, J., \& Levien, R. (2010). Métodos de preparo do solo e sua influência na erosão hídrica e no acúmulo de biomassa na parte aérea de Eucalyptus saligna em um cambissolo háplico da depressão central do rio Grande do Sul. Revista Árvore, 34(4), 567-575. http://dx.doi.org/10.1590/S0100-67622010000400001.

Cheng, L. C., Scapin, C. A., Oliveira, C. A., Krafestuski, E., Drumond, F. B., Boan, F. S., Prates, L. B., \& Vilela, R. M. (1995). QFD: planejamento da qualidade (262 p.). Belo Horizonte: Fundação Christiano Ottoni.

Cordeiro, S. A., Silva, M. L., Jacovine, L. A. G., Valverde, S. R., Rocha, J. L., \& Soares, N. S. (2009). Desempenho do fomento do órgão florestal de Minas Gerais. Cerne, 15(3), 273-281.

Cox, M. S., Gerard, P. D., Wardlaw, M. C., \& Abshire, M. J. (2003). Variability of selected soil properties and their relaionships with soybean yield. Soil Science Society of America Journal, 67(4), 1296-1302. http://dx.doi.org/10.2136/sssaj2003.1296.

Elbanna, E. B., \& Witney, B. D. (1987). Cone penetration resistance equations as a function of the clay ratio, soil moisture content and specific weight. Journal of Terramechanics, 24(1), 41-56. http://dx.doi.org/10.1016/0022-4898(87)90058-9.

Gonçalves, J. L. M., Stape, J. L., Laclau, J. P., Smethurst, P., \& Gava, J. L. (2004). Silvicultural effects on the productivity and wood quality of eucalyptus plantations. Forest Ecology and Management, 193(1-2), 575-585. http://dx.doi.org/10.1016/j.foreco.2004.01.022. 
Gonçalves, S. B., Lopes, E. S., Fiedler, N. C., Cavalieri, K. M. V., Stahl, J., \& Drinko, C. H. F. (2016). Efeito da profundidade de trabalho na qualidade da operação da subsolagem para implantação florestal. Revista Árvore, 40(1), 29-37. http://dx.doi.org/10.1590/0100-67622016000100004.

Govers, C. (1996). What and about quality function deployment (QFD). International Journal of Production Economics, 46, 575-585. http://dx.doi.org/10.1016/0925-5273(95)00113-1.

Juran, J. M. (1992). Juran on quality by design: the new steps for planning quality into goods and services (538 p.). New York: Free Press.

Kim, T. J., Bullock, B. P., \& Stape, J. L. (2015). Effects of silvicultural treatments on temporal variations of spatial autocorrelation in Eucaliyptus plantations in Brazil. Forest Ecology and Management, 358, 9097. http://dx.doi.org/10.1016/j.foreco.2015.09.004.

Medauar, C. C., Silva, S. A., Carvalho, L. C. C., Tibúrcio, R. A. S., \& Lima, J. S. S. (2018). Espectro de gotas e distribuição de calda de herbicida associada a fertilizante foliar em área de reforma florestal. Scientia Forestalis, 46(119), 333-345. http://dx.doi.org/10.18671/scifor.v46n119.01.

Milan, M., Barros, J. W. D., \& Gava, J. L. (2003). Planning soil tillage using quality function deployment (QFD). Scientia Agrícola, 60(2), 217-221. http://dx.doi.org/10.1590/S0103-90162003000200003.

Schönau, A. P. G. (1984). Silvicultural considerations for high productivity eucaliptus grandis. Forest Ecology and Management, 9(4), 295-314. http://dx.doi.org/10.1016/0378-1127(84)90015-X.

Soares, P. R. C., Timofeiczyk Junior, R., Silva, J. C. G. L., \& Milan, M. (2015). Sistema de medição de performance para o controle de plantas invasoras em plantações florestais. Floresta, 45(1), 175-184. http://dx.doi.org/10.5380/rf.v45i1.35996.

Zairi, M., \& Youssef, M. (1995). Quality function deployment: a main pillar for successful total quality management and product development. International Journal of Quality \& Reliability Management, 12(6), 9-23. http://dx.doi.org/10.1108/02656719510089894.

Authors' contributions: DCVC: Conceptualization, Data curation, Formal Analysis, Funding acquisition, Investigation, Methodology, Project administration, Writing - original draft, Validation; TLR: Conceptualization, Supervision, Validation, Visualization, Data curation Formal Analysis, Writing - original draft, Writing - review \& editing; LMG: Validation, Writing - review \& editing; MM: Conceptualization, Supervision, Validation, Resources, Data curation, Formal Analysis, Visualization, Writing - original draft, Writing - review \& editing. 